\title{
High Temperature Alkaline Electrolysis Cells with Metal Foam Based Gas Diffusion
} Electrodes

\author{
Chatzichristodoulou, Christodoulos; Allebrod, Frank; Mogensen, Mogens Bjerg
}

Published in:

Journal of The Electrochemical Society

Link to article, DOI:

$10.1149 / 2.0051611$ jes

Publication date:

2016

Document Version

Publisher's PDF, also known as Version of record

Link back to DTU Orbit

Citation (APA):

Chatzichristodoulou, C., Allebrod, F., \& Mogensen, M. B. (2016). High Temperature Alkaline Electrolysis Cells with Metal Foam Based Gas Diffusion Electrodes. Journal of The Electrochemical Society, 163(11), F3036F3040. https://doi.org/10.1149/2.0051611jes

\section{General rights}

Copyright and moral rights for the publications made accessible in the public portal are retained by the authors and/or other copyright owners and it is a condition of accessing publications that users recognise and abide by the legal requirements associated with these rights.

- Users may download and print one copy of any publication from the public portal for the purpose of private study or research.

- You may not further distribute the material or use it for any profit-making activity or commercial gain

- You may freely distribute the URL identifying the publication in the public portal 


\title{
High Temperature Alkaline Electrolysis Cells with Metal Foam Based Gas Diffusion Electrodes
}

\author{
C. Chatzichristodoulou, ${ }^{\mathrm{a}, \mathrm{z}}$ F. Allebrod, ${ }^{\mathrm{b}}$ and M. B. Mogensen ${ }^{\mathrm{a}, *}$ \\ ${ }^{a}$ Technical University of Denmark, Department of Energy Conversion and Storage, 4000 Roskilde, Denmark \\ ${ }^{b}$ H-TEC SYSTEMS GmbH, 23562 Lübeck, Germany
}

\begin{abstract}
Alkaline electrolysis cells operating at $250^{\circ} \mathrm{C}$ and 40 bar are able to convert electrical energy into hydrogen at very high efficiencies and power densities. In the present work we demonstrate the application of a PTFE hydrophobic network and Ag nanowires as oxygen evolution electrocatalyst in the metal foam based gas diffusion electrodes. A novel cell production method, based on tape casting and hot pressing, was developed which allows to increase the cell size from lab scale $\left(1 \mathrm{~cm}^{2}\right)$ to areas of $25 \mathrm{~cm}^{2}$ or larger. The thickness of the electrolyte matrix could be adjusted to only $200 \mu \mathrm{m}$, achieving a serial resistance and total area specific resistance of only $60 \mathrm{~m} \Omega \mathrm{cm}^{2}$ and $150 \mathrm{~m} \Omega \mathrm{cm}^{2}$, respectively, at $200^{\circ} \mathrm{C}$ and 20 bar, yielding a record high current density of $3.75 \mathrm{~A} \mathrm{~cm}^{-2}$ at a cell voltage of $1.75 \mathrm{~V}$. Encouraging long-term stability was obtained over $400 \mathrm{~h}$ of continuous electrolysis. This novel cell concept promises more than a 10 -fold improvement in power density, compared to conventional alkaline electrolysis cells, and thereby equivalent reduction in stack size and cost.

(C) The Author(s) 2016. Published by ECS. This is an open access article distributed under the terms of the Creative Commons Attribution 4.0 License (CC BY, http://creativecommons.org/licenses/by/4.0/), which permits unrestricted reuse of the work in any medium, provided the original work is properly cited. [DOI: 10.1149/2.0051611jes] All rights reserved.
\end{abstract}

Manuscript submitted April 6, 2016; revised manuscript received May 11, 2016. Published May 18, 2016. This was Paper 1235 presented at the Cancun, Mexico, Meeting of the Society, October 5-9, 2014. This paper is part of the JES Focus Issue on Electrolysis for Increased Renewable Energy Penetration.

In order to accommodate the rapidly increasing contribution of intermittent renewable energy sources to the energy supply system, efficient and large scale energy storage technologies are needed. ${ }^{1-3}$ Hydrogen production through electrolysis of water offers a promising technology for large scale grid storage, as well as a sustainable route to $\mathrm{H}_{2}$ production for the chemical industry.

Systems based on alkaline electrolysis cells (AECs) represent a very mature technology that is the current standard for large-scale $\mathrm{H}_{2}$ production. A number of companies are active in the field and have demonstrated MW-scale alkaline electrolysis systems with stable operation for many years. ${ }^{4}$ The alkaline electrolysers that are commercially available today operate at $60-100^{\circ} \mathrm{C}, 1-30 \mathrm{~atm}$, and at a current density of $200-500 \mathrm{~mA} \mathrm{~cm}^{-2}$ with an efficiency of $50-80 \% .^{4}$

Broader deployment of AEC systems is hindered by the relatively high cost for hydrogen production. The milestone report published by the National Renewable Energy Laboratory (NREL) ${ }^{5}$ suggests that electricity costs comprise $80 \%$ of the total selling price of hydrogen from large-scale alkaline electrolysers. This emphasizes the need for improvement in the electrical energy efficiency of such systems. Besides improving cell efficiency, it is beneficial to increase the production rate, and decrease capital cost. Since conventional alkaline electrolysis technology has reached maturation, only small incremental improvements can be expected.

To achieve a drastic step forward, we have developed a new generation of AECs that can operate at elevated temperature and pressure, producing pressurized hydrogen at high rate and high electrical efficiency. ${ }^{6-8}$ The concept relies on the development of corrosion resistant high temperature diaphragms, based on mesoporous ceramic membranes where aqueous $\mathrm{KOH}$ is immobilized by capillary forces, ${ }^{9}$ in combination with gas diffusion electrodes that overcome mass transport limitations at large production rates. Raising the operating temperature offers a means to drastically improve performance, as both ionic transport and reaction kinetics are exponentially activated with temperature. Indeed, we have demonstrated AECs operating at temperatures up to $250{ }^{\circ} \mathrm{C}$ at 40 bar, yielding current densities of up to $1.1 \mathrm{~A} \mathrm{~cm}^{-2}$ and $2.3 \mathrm{~A} \mathrm{~cm}^{-2}$ at cell voltages of $1.5 \mathrm{~V}$ and $1.75 \mathrm{~V}$, corresponding to electrical efficiencies (based on the higher heating value of $\mathrm{H}_{2}$ ) of almost $99 \%$ and $85 \%$, respectively, using lab-scale size cells $\left(1 \mathrm{~cm}^{2}\right){ }^{8}$ The corresponding efficiencies based on the lower

\footnotetext{
*Electrochemical Society Fellow.
}

${ }^{z}$ E-mail: ccha@dtu.dk heating value of $\mathrm{H}_{2}$ are $82 \%$ and $70 \%$, respectively. To which extent the heat generated in the cell can be utilized for steam generation will depend on the system design. These current densities correspond to ca. 5-fold increase in $\mathrm{H}_{2}$ production rate compared to conventional AECs operated at $80-100^{\circ} \mathrm{C}$. Long-term operation at $250^{\circ} \mathrm{C}$ was also demonstrated for $350 \mathrm{~h}$, but suggested relatively fast oxidation of the Ni foam at the anode. ${ }^{10}$

In the present work we explore the application of a PTFE hydrophobic network in the foam based oxygen electrode and $\mathrm{Ag}$ nanowires as oxygen evolution electrocatalyst. Furthermore, we have replaced the $\mathrm{Ni}$ foam at the anode with a $\mathrm{NiFeCrAl}$ alloy foam to reduce the oxidation rate of the metal foam under long-term operation in the strongly oxidizing conditions of the anode during the oxygen evolution reaction. A novel cell production method, based on tape casting, hot pressing, and sintering was also developed which enables cost-efficient up-scaling of production to cell areas of $25 \mathrm{~cm}^{2}$ or higher. Finally, the long-term stability of the cells was evaluated over $400 \mathrm{~h}$ of continuous electrolysis at $200^{\circ} \mathrm{C}$ and 20 bar.

\section{Experimental}

Production of electrolyte matrix tape.-Yttria-stabilized zirconia (YSZ) tape was produced using tape casting. $300 \mathrm{~g}$ of YSZ powder (TZ-3Y, Tosoh) was mixed with $130 \mathrm{~g}$ Ethanol and $40.4 \mathrm{~g}$ Polyvinylpyrrolidone (PVP) as binder. The slurry was treated by ball milling with $1000 \mathrm{~g} \mathrm{3/8}$ " balls for $72 \mathrm{~h}$ in a 21 container with 50 rpm before $145.6 \mathrm{~g}$ of an appropriate binder was added. Thereafter the slurry was mixed for another $24 \mathrm{~h}$ at $25 \mathrm{rpm}$. After filtering and de-airing in vacuum the slurry was filled in the tape caster and a tape was produced with a speed of $20 \mathrm{~cm} \mathrm{~min}^{-1}$ and a doctoral blade height of $80 \mu \mathrm{m}$. After drying for another $24 \mathrm{~h}$ the tape was ready to use.

Assembly of the foam based alkaline electrolysis cells (FobAECs).-Nickel-based metal foams of a thickness of $1.5 \mathrm{~mm}$ and a porosity of ca. $95 \%$ were pressed in a hot press at $200^{\circ} \mathrm{C}$ to reduce the thickness to ca. $0.5 \mathrm{~mm}$. The used foams were either pure Nickel foam, or Nickel foam coated by Inconel 625 or NiFeCrAl alloy delivered by Alantum. The produced YSZ tape was placed in between two metal foam layers $\left(5 \times 5 \mathrm{~cm}^{2}\right)$ and pressed at $200^{\circ} \mathrm{C}$ for $30 \mathrm{~s}$. The final cell thickness was chosen to be $100 \mu \mathrm{m}$ less than the sum of the two foams and the tape in order to achieve partial penetration of the foams into the YSZ tape. The cells were sintered in air at $200^{\circ} \mathrm{C}$, 
$420^{\circ} \mathrm{C}$ and $600^{\circ} \mathrm{C}$ for $4 \mathrm{~h}$ with a heating ramp of $15 \mathrm{~K} \mathrm{~h}^{-1}$, followed by a second sintering step in $9 \% \mathrm{H}_{2}$ (Ar balance) at $1000^{\circ} \mathrm{C}$ for $6 \mathrm{~h}$ with a heating and cooling ramp of $40 \mathrm{~K} \mathrm{~h}^{-1}$. Fabricated square cells $\left(5 \times 5 \mathrm{~cm}^{2}\right)$ with $\mathrm{Ni}$ or $\mathrm{NiFeCrAl}$ alloy foam based oxygen electrode (OE) and an Inconel foam hydrogen electrode (HE) was laser-cut into circular cells $(1 \mathrm{~cm}$ in diameter) for electrochemical testing in a high temperature and pressure electrochemical test station. ${ }^{11}$

Porosimetry.-Mercury porosimetry was performed with an AutoPore IV 9500 analyzer, since the porosity and pore size distribution of the YSZ structure is of high interest for the immobilization of the aqueous electrolyte. The sample for porosimetry was produced similar to the FobAECs, but without the foams pressed on the two sides of the YSZ tape.

Impregnation of the anode with PTFE and Ag nanowires.-A dispersion with $100 \mathrm{mg}$ PTFE powder with particle size of $1 \mu \mathrm{m}$ (Sigma-Aldrich, 430935), 5 drops dispersant (X-100, Sigma-Aldrich) and $100 \mathrm{mg}$ ammonium bicarbonate (Sigma-Aldrich, 11213) as poreformer were mixed with a Ag nanowire dispersion $(115 \mathrm{~nm} \times 20-50$ $\mu \mathrm{m}$ (diameter $\times$ length), Sigma-Aldrich, 739448). 5 drops of the dispersion were dropped on the OE of the cell which was laser cut as described earlier. The cell was then calcined for $1 \mathrm{~h}$ at $300^{\circ} \mathrm{C}$ with a heating and cooling ramp of $50 \mathrm{~K} \mathrm{~h}^{-1}$. PTFE particles were preferred to Teflon AF to prevent hydrophobization of the porous electrolyte matrix of the cells.

Electrochemical measurements.-Electrochemical measurements, i.e. electrochemical impedance spectroscopy (EIS) and cyclic voltammetry $(\mathrm{CV})$, were performed in order to determine the cell characteristics during operation as an electrolysis cell. A Gamry Reference 3000 potentiostat was used to conduct the measurements. Cyclic voltammograms were recorded starting from open circuit voltage $(\mathrm{OCV})$, increasing the cell voltage to $1.75 \mathrm{~V}$, and then returning to OCV. EIS has been performed under a cell polarization of $1.5 \mathrm{~V}$. The total area specific resistance (ASR) $\left[\mathrm{m} \Omega \mathrm{cm}^{2}\right]$ and the serial resistance $\left(\mathrm{R}_{\mathrm{S}}\right)\left[\mathrm{m} \Omega \mathrm{cm}^{2}\right]$ of the cells were determined from the impedance measurements under polarization without any corrections. The FobAECs were immersed in $45 \mathrm{wt} \% \mathrm{KOH}$ prior to the measurements to fill the electrolyte matrix with aqueous $\mathrm{KOH}$ electrolyte. A high temperature and pressure electrochemical test station that enables electrochemical testing in the temperature range of $25-280^{\circ} \mathrm{C}$ and pressure range of 1-100 bar was used for the cell testing. The entire system, including a sample holder for simultaneous measurements of four cells, has been described in detail elsewhere. ${ }^{11}$ The measurements reported here were carried out at a pressure of 20 bar and temperature of $200^{\circ} \mathrm{C}$. The $\mathrm{OE}$ was constantly flushed with a gas mixture of $30 \% \mathrm{H}_{2} \mathrm{O}(\mathrm{g}), 5 \% \mathrm{O}_{2}$ and $65 \% \mathrm{~N}_{2}$ while the HE was flushed with pure $\mathrm{H}_{2}$.

\section{Results}

Physical structure of the produced cells.-Figure 1 shows a SEM micrograph of the cross section of a FobAEC with two Inconel foam electrodes and the electrolyte matrix. The thickness of each foam and of the electrolyte matrix was ca. $450 \mu \mathrm{m}$ and $180 \mu \mathrm{m}$, respectively. The YSZ layer adapted to the shape of the foams, while the foams did not penetrate deep into the electrolyte matrix. The foams remained very porous despite being pressed prior to cell assembling.

Porosimetry analysis.-The pore size distribution of the YSZ electrolyte matrix used for immobilization of the aqueous $\mathrm{KOH}$ was characterized by $\mathrm{Hg}$ porosimetry, the results of which are shown in Figure 2 . The mean pore size was found to be $70 \mathrm{~nm}$ with a porosity of $45.0 \%$.

Hydrophobic layer.-A PTFE dispersion with Ag nanowires was used to impregnate the metal foam OE of the FobAEC, as described earlier. The PTFE particles adhered well to the metal surface of the foam as can be seen in Figure 3. The pore size of the foam was

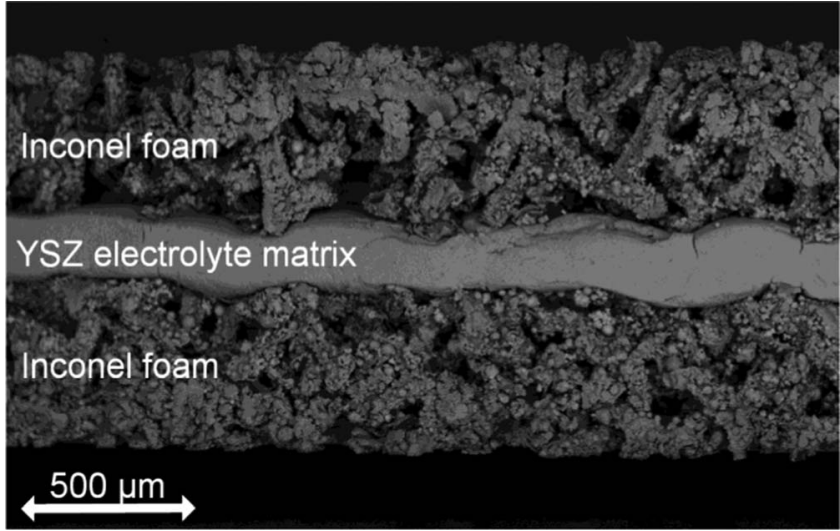

Figure 1. SEM micrograph of the cross section of a FobAEC with Inconel foam electrodes and a porous YSZ electrolyte matrix.

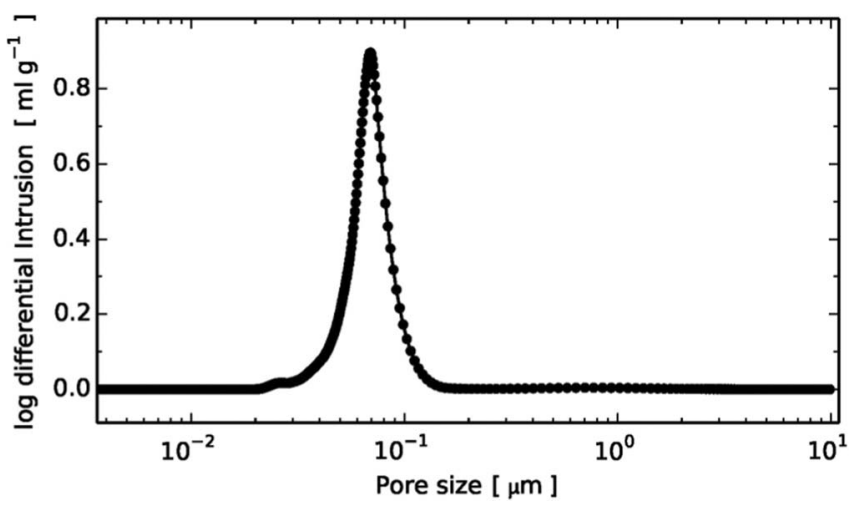

Figure 2. Results of the mercury intrusion porosimetry of the electrolyte supporting porous YSZ structure showing a mean pore size of $70 \mathrm{~nm}$.

typically around $250 \mu \mathrm{m}$. The PTFE coating was almost completely covering the surface of the foam at the outer side of the cell, while the coverage was reduced toward the inner part of the foam neighboring the electrolyte matrix to ca. 5-20\% (rough estimate based on SEM images). The pore size of the PTFE coating was typically around $1 \mu \mathrm{m}$, but also bigger pores $(\approx 10 \mu \mathrm{m})$ were identified.
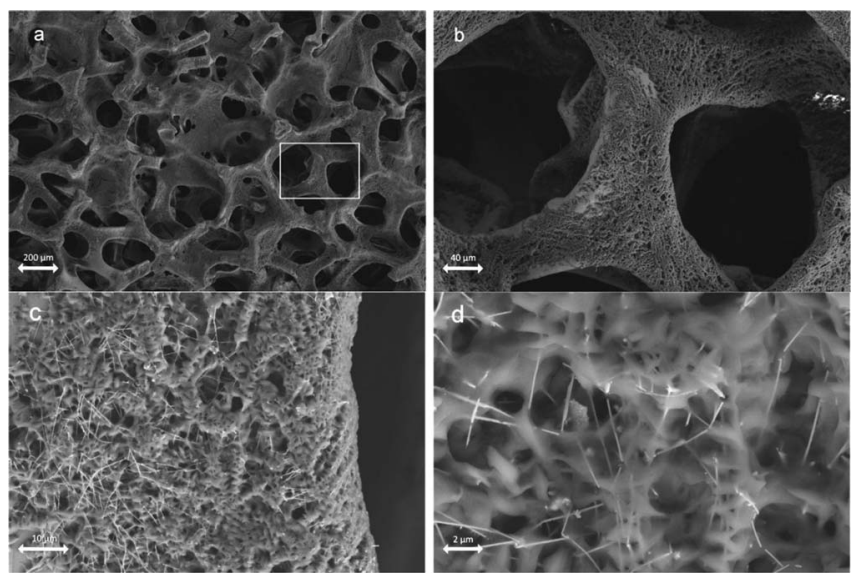

Figure 3. SEM images of the oxygen electrode with increasing magnification from a to $d$. The images show the metal foam, coated with a dispersion containing PTFE and Ag nanowires. The porous nature of the PTFE coating is obvious in b and c, while the PTFE-bonded Ag nanowires can be seen in image $d$. 

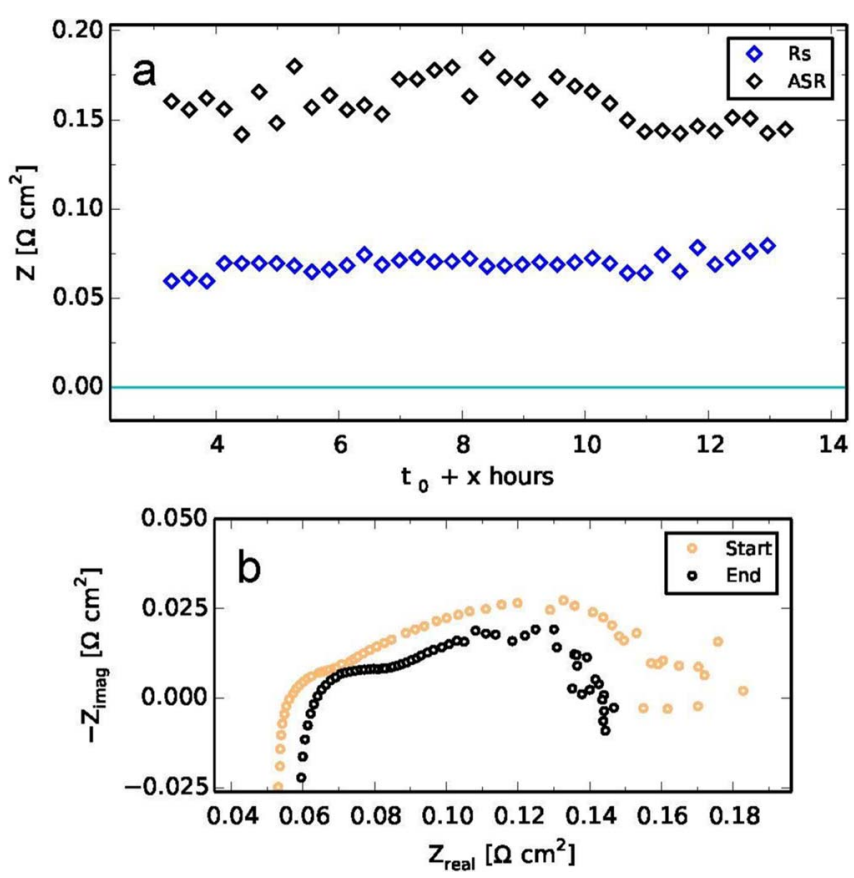

Figure 4. Impedance results of a foam based alkaline electrolysis cell at $200^{\circ} \mathrm{C}$ and 20 bar at a cell voltage of $1.5 \mathrm{~V}$. a) Rs and ASR of the cell over a period of $10 \mathrm{~h}$. b) Nyquist plot of the corresponding measurements at the beginning and at the end of the session. The $\mathrm{OE}$ was constantly flushed with a gas mixture of $30 \% \mathrm{H}_{2} \mathrm{O}(\mathrm{g}), 5 \% \mathrm{O}_{2}$ and $65 \% \mathrm{~N}_{2}$ while the $\mathrm{HE}$ was flushed with pure $\mathrm{H}_{2}$.

Electrolysis test at $200^{\circ} \mathrm{C}$ and 20 bar.-A FobAEC with $\mathrm{Ni}$ foam based OE, impregnated with PTFE and Ag nanowires, and Inconel foam $\mathrm{HE}$ (without further catalysts or coating) was characterized electrochemically. The measured $\mathrm{R}_{\mathrm{S}}$ and ASR are shown in Figure $4 \mathrm{a} . \mathrm{R}_{\mathrm{S}}$ (measured at $390 \mathrm{kHz}$ ) increased from $58 \mathrm{~m} \Omega \mathrm{cm}^{2}$ to $78 \mathrm{~m} \Omega \mathrm{cm}^{2}$ and the ASR (measured at $1 \mathrm{~Hz}$ ) decreased from $162 \mathrm{~m} \Omega \mathrm{cm}^{2}$ to 144 $\mathrm{m} \Omega \mathrm{cm}^{2}$ during the $10 \mathrm{~h}$ lasting impedance measurements. Figure $4 \mathrm{~b}$ displays the Nyquist plot of the corresponding measurements at the beginning and at the end of the $10 \mathrm{~h}$ long session. The data at the low frequency part (higher values of $\mathrm{Z}_{\text {real }}$ ) are rather scattered.

Cyclic voltammetry (CV) was performed at $200^{\circ} \mathrm{C}$ and 20 bar with a sweep rate of $20 \mathrm{mV} / \mathrm{s}$. Figure $5 \mathrm{~A}$ shows a $\mathrm{CV}$ obtained before

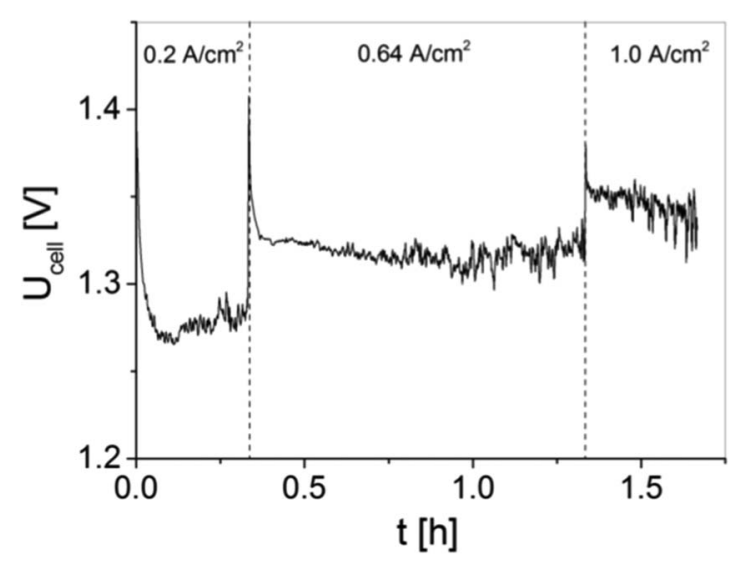

Figure 6. Chronopotentiometry (CP) of the analyzed foam based alkaline electrolysis cell with PTFE and Ag nanowires coated anode (oxygen electrode) and Inconel foam cathode (hydrogen electrode) at $200^{\circ} \mathrm{C}$ and 20 bar recorded at current densities of $0.2,0.64$ and $1 \mathrm{~A} \mathrm{~cm}^{-2}$.

the impedance measurements described above, Figure 5B thereafter. The current density at a cell voltage $\mathrm{U}_{\text {Cell }}$ of $1.5 \mathrm{~V}$ and $1.75 \mathrm{~V}$ was $0.75 \mathrm{~A} \mathrm{~cm}^{-2}$ and $3.0 \mathrm{~A} \mathrm{~cm}^{-2}$, respectively, before the impedance measurements. After the impedance measurements the current density at $1.5 \mathrm{~V}$ was $0.9 \mathrm{~A} \mathrm{~cm}^{-2}$ at the positive and $1.75 \mathrm{~A} \mathrm{~cm}^{-2}$ at the negative loop of the CV. At $1.75 \mathrm{~V}$ it was $3.75 \mathrm{~A} \mathrm{~cm}^{-2}$.

It should be pointed out here that current densities recorded during cyclic voltammetry may deviate from steady state values. Chronopotentiometry was thus performed in order to determine steady state performance values. As shown in Figure 6, the steady state cell voltage is similar to that recorded during the negative loop (decreasing cell voltage) of the CV shown in Figure $5 \mathrm{~b}$, for current densities up to $1 \mathrm{~A} \mathrm{~cm}^{-2}$. It is therefore reasonable to assume that this part of the $\mathrm{CV}$ is representative of the steady state response of the cell.

Post mortem analysis of the $\mathrm{O}_{2}$ electrode.-The OE of a FobAEC, similar to the one shown in Figure 3, has been analyzed by SEM and EDS after $140 \mathrm{~h}$ exposure at $200^{\circ} \mathrm{C}$ and $20 \mathrm{bar}$, including the electrochemical measurements described above. Figure 7 shows the SEM analysis of the OE. The Ni foam in Figure 7a appears to retain its original structure. Higher magnification views reveal that the PTFE coating still covers most of the outer metal surface, but its microstructure has become somewhat rougher and more irregular. The Ag nanowires
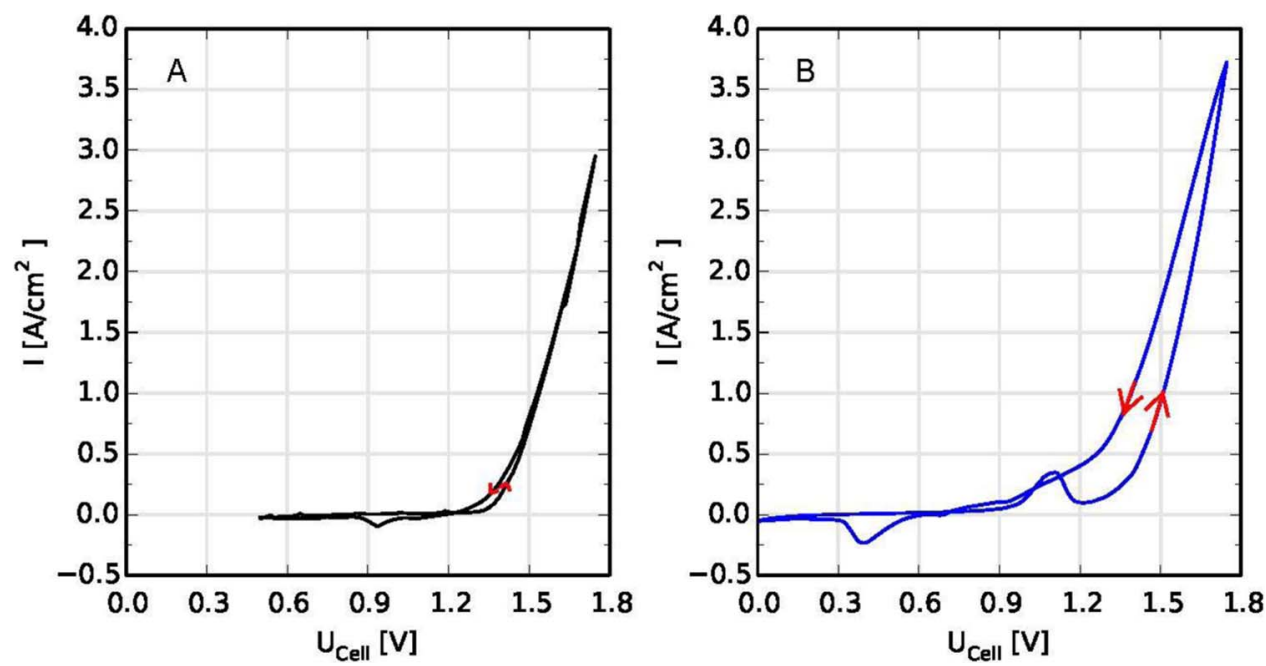

Figure 5. Cyclic voltammogram (CV) of the analyzed foam based alkaline electrolysis cell with PTFE and Ag nanowires coated anode (oxygen electrode) and Inconel foam cathode (hydrogen electrode) at $200^{\circ} \mathrm{C}$ and 20 bar recorded with a sweep rate of $20 \mathrm{mV} / \mathrm{s}$. A shows the CV before and B after the $10 \mathrm{~h}$ lasting series of impedance measurements at a cell voltage of $1.5 \mathrm{~V}$. The arrows indicate the direction of the $\mathrm{CV}$. 

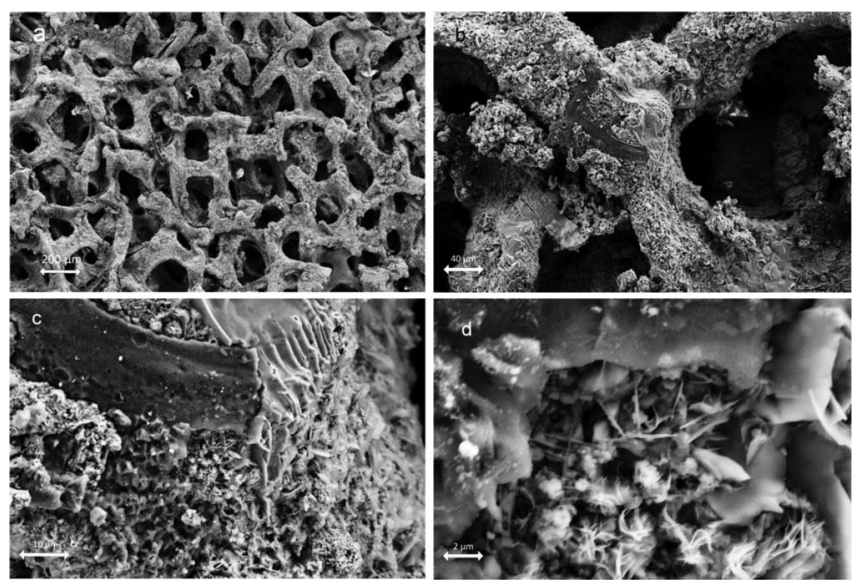

Figure 7. Post mortem analysis of the oxygen electrode of a cell similar to the one shown in Figure 3. Image (a) shows that the Ni foam retains its original structure. Higher magnification images (b)-(d) reveal a substantially modified surface structure, but the PTFE coating (c) and some Ag nanowires (d) are still partly covering the metal surface.

were only found at limited areas (approx. 1\%) of the foam's outer surface. Figure 8 shows (a) a SEM micrograph of the OE area analyzed by EDS, and the corresponding (b) fluorine (indicative of PTFE) and (c) Ag distribution. Fluorine is well distributed over the foam verifying that the PTFE layer is still in place in line with the SEM observations. The EDS mapping of Ag also points toward a homogeneous distribution of the Ag nanowires over the foam's surface.

Long-term electrolysis test at $200^{\circ} \mathrm{C}$ and 20 bar.-The long-term performance of a FobAEC, comprising a NiFeCrAl alloy foam $\mathrm{OE}$ (impregnated with PTFE and Ag nanowires) and an Inconel foam HE was examined over a $400 \mathrm{~h}$ duration continuous electrolysis experiment at $200^{\circ} \mathrm{C}$ and 20 bar at a current density of $500 \mathrm{~mA} \mathrm{~cm}{ }^{-2}$. As can be seen in Figure 9, the starting performance of the cell was far inferior to that of the cell presented earlier in Figures 4 and 5. The $R_{s}$ was 3-4 times larger, despite the similar thickness and microstructural properties of the electrolyte supporting matrix, whereas the $R_{P}$ of the cell was ca. 3 times larger. Nevertheless, the long-term performance of the cell appears rather stable, with a fluctuation of the order of $20 \%$ around a value of $0.2 \Omega \mathrm{cm}^{2}$ for the $\mathrm{R}_{\mathrm{s}}$ and $0.5 \Omega \mathrm{cm}^{2}$ for the ASR. The cell voltage also remained rather stable at $1.5 \pm 0.1 \mathrm{~V}$.

\section{Discussion}

Cell production.-Fabrication of FobAECs by tape casting, hot pressing and sintering was successfully demonstrated at a cell size of $5 \times 5 \mathrm{~cm}^{2}$, using metal foam based electrodes and a porous YSZ
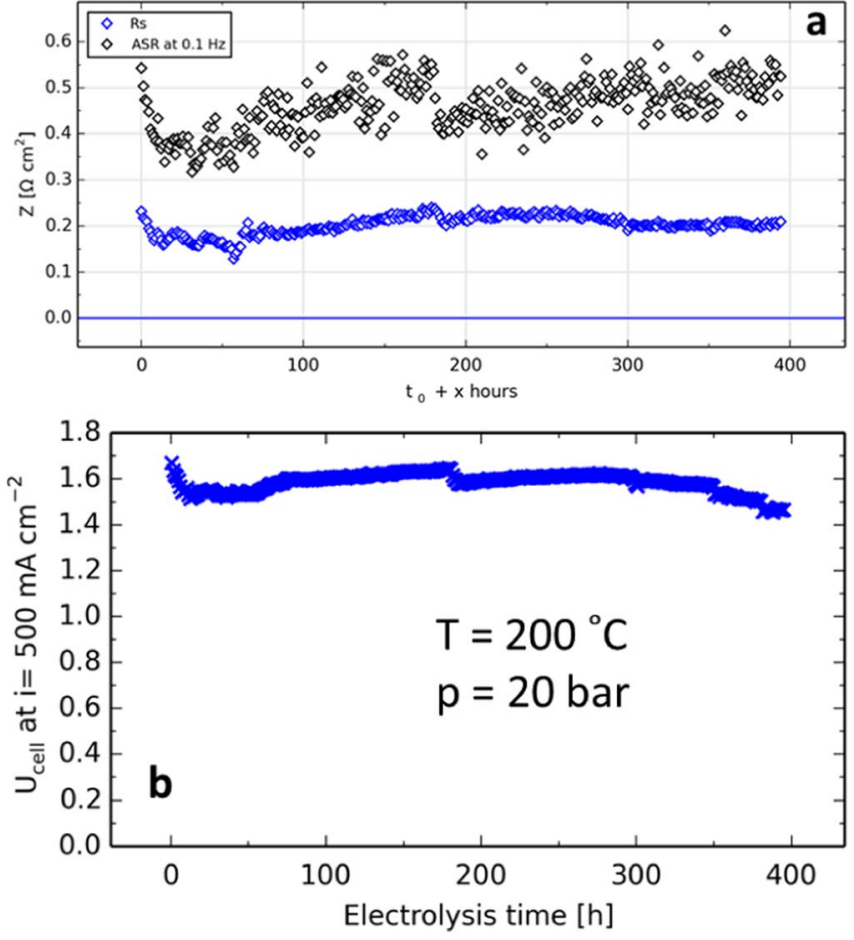

Figure 9. a) $R_{s}$ and ASR and b) chronopotentiometry of a FobAEC during $400 \mathrm{~h}$ of continuous electrolysis operation at $200^{\circ} \mathrm{C}$ and 20 bar at a current density of $500 \mathrm{~mA} \mathrm{~cm}{ }^{-2}$. The cell comprised a $\mathrm{NiFeCrAl}$ alloy foam $\mathrm{OE}$, impregnated with PTFE and Ag nanowires, and an Inconel foam $\mathrm{HE}$. The $\mathrm{OE}$ was constantly flushed with a gas mixture of $30 \% \mathrm{H}_{2} \mathrm{O}(\mathrm{g}), 5 \% \mathrm{O}_{2}$ and $65 \%$ $\mathrm{N}_{2}$ while the $\mathrm{HE}$ was flushed with pure $\mathrm{H}_{2}$.

matrix. Up-scaling to significantly larger cells $\left(>20 \times 20 \mathrm{~cm}^{2}\right)$ is in principle possible using this cost-effective production method.

The electrode surface was rendered hydrophobic by applying a PTFE coating using a PTFE dispersion. The distribution of PTFE ranged from almost complete coverage at the outer parts of the metal foam to a limited coverage (estimated to ca. 5-20\%) near the electrolyte support matrix. This reduced hydrophobicity at the active electrode part is expected to be beneficial for the electrode performance. Ag nanowires which were applied along with the PTFE dispersion showed a similar distribution; therefore the catalyst loading is lower at the active electrode part, which is contra-productive. Better cell performance may be expected if the coating method can be modified to increase the catalyst concentration at the inner parts of the foam-based electrode, while improving the cost/performance ratio.

Electrochemical performance.-The impedance measurements showed that $R_{S}$ increased by $20 \mathrm{~m} \Omega \mathrm{cm}^{2}$ while the ASR decreased
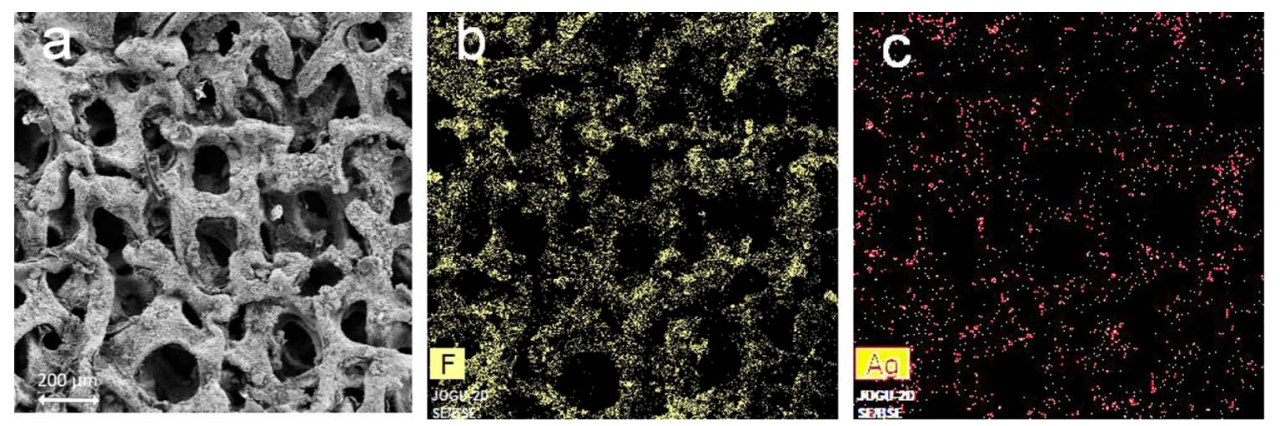

Figure 8. Post mortem EDS mapping of the oxygen electrode after the electrochemical testing. a) shows the top view image of the electrode, b) shows the fluorine distribution (as an indication of the PTFE distribution) and c) shows the Ag distribution of the area shown in a). 
by $18 \mathrm{~m} \Omega \mathrm{cm}^{2}$ during the first $10 \mathrm{~h}$ of polarization at a cell voltage of $1.5 \mathrm{~V}$. Therefore the $\mathrm{R}_{\mathrm{P}}$ improved (decreased) from $104 \mathrm{~m} \Omega \mathrm{cm}^{2}$ to $66 \mathrm{~m} \Omega \mathrm{cm}^{2}$ from the beginning to the end of the measurement. The SEM analysis (Figure 7) showed that the microstructure of the coating layer at the surface of the foam became rougher after the measurements. This microstructural modification has likely increased the active surface area (area of the foam wetted by the electrolyte), thereby improving the cell performance and causing the significantly improved $\mathrm{R}_{\mathrm{P}}$.

Furthermore, it is possible that the cell heated locally during the tests, reaching a temperature above $200^{\circ} \mathrm{C}$. A thermocouple situated ca. $1 \mathrm{~cm}$ away from the cell measured a temperature increase of only $2 \mathrm{~K}$ during the impedance measurements, but it is most likely that the temperature increased to higher values at the active part of the electrode and in the electrolyte. This could be the reason for the pronounced hysteresis observed in Figure $5 \mathrm{~b}$, where the performance was significantly improved on the falling curve than on the rising curve. The current density of $3.75 \mathrm{~A} \mathrm{~cm}^{-2}$ at $1.75 \mathrm{~V}$ results in a power density of $6.6 \mathrm{~W} \mathrm{~cm}^{-2}$ and a cell power $\mathrm{P}_{\text {Cell }}$ of $5.2 \mathrm{~W}$. The thermo-neutral voltage $\mathrm{E}_{\mathrm{tn}}$ at $200^{\circ} \mathrm{C}$ for steam electrolysis is $1.26 \mathrm{~V}^{7}$ The surplus power that will be transformed to heat can be calculated by Equation 1, where $\mathrm{I}_{\text {Cell,tot }}$ is the total (not area normalized) cell current. The corresponding $\mathrm{P}_{\text {loss }}$ at a cell voltage $\mathrm{U}_{\text {Cell }}=1.75 \mathrm{~V}$ and $\mathrm{I}_{\text {Cell,tot }}=2.95 \mathrm{~A}$ is $1.45 \mathrm{~W}$. Assuming a heat transfer resistance $R_{\theta}$ of $10 \mathrm{~K} \mathrm{~W}^{-1}$ for the cell and the sample holder (based on heat sinks of comparable size and form), a temperature difference $\Delta \theta=14.5 \mathrm{~K}$ is estimated from the ambient to the surface of the sample holder using Equation 2. It should be stressed out though that the estimation of the heat transfer resistance is rather uncertain; experimental data to determine the exact value are currently missing.

$$
\begin{gathered}
\mathrm{P}_{\text {loss }}=\left(\mathrm{U}_{\text {Cell }}-\mathrm{E}_{\mathrm{tn}}\right) \mathrm{I}_{\text {Cell, tot }} \\
\Delta \theta=\mathrm{R}_{\theta} \times \mathrm{P}_{\text {Loss }}
\end{gathered}
$$

The achieved performance is substantially superior to that achieved previously ${ }^{8}$ at even higher temperatures $\left(2.3 \mathrm{~A} \mathrm{~cm}^{-2}\right.$ at $1.75 \mathrm{~V}, 250^{\circ} \mathrm{C}$ and 40 bar). The improved performance is largely due to the reduced $\mathrm{R}_{\mathrm{s}}$, which was rate determining in Ref. 8, achieved by reducing the electrolyte matrix thickness from $1300 \mu \mathrm{m}$ to $200 \mu \mathrm{m}$. The PTFE hydrophobic coating and $\mathrm{Ag}$ nanowires used in the anode have also caused a 3-fold decrease in the cell $\mathrm{R}_{\mathrm{P}}$, corresponding to a more than 3-fold decrease of the $R_{P}$ of the OE, in comparison to that in Ref. 8 . The decreased $R_{P}$ is likely associated with the increased electroactive surface area achieved by the introduction of the $\mathrm{Ag}$ nanowires.

The performance of the FobAEC over a $400 \mathrm{~h}$ duration continuous electrolysis experiment at $200^{\circ} \mathrm{C}$ and 20 bar was rather stable, albeit approx. 3 times inferior to the short-term tested cell. The 3-4 times larger $R_{s}$, despite the similar thickness and microstructure of the electrolyte supporting layer, suggests a substantially larger contacting resistance (associated with the set-up of the test) as the main reason for the inferior performance. This has likely also influenced the $R_{P}$ of the cell, which was ca. 3 times larger. In any case, the replacement of the $\mathrm{Ni}$ foam with a $\mathrm{NiFeCrAl}$ alloy coated $\mathrm{Ni}$ foam at the OE proved to be very effective in terms of improving the long-term stability of this electrode by limiting the rate of oxidation of the metal foam surface, as a comparison with the results presented in Ref. 10 reveals. Furthermore, the PTFE hydrophobic coating developed here proved successful in overcoming flooding of the active electrode region and trapping of $\mathrm{O}_{2}$ bubbles that was observed in Ref. 10 .

The substantially enhanced performance of FobAECs versus conventional AECs enables drastic downsizing of the electrolysis stack. The weight and space demand of a classical, well proven and commercially available alkaline electrolysis system, comprising $150 \mathrm{NEL}$ A 485 electrolysers, was compared to a FobAEC-based system vision in a previous study. ${ }^{12}$ The power density of a conventional alkaline electrolysis stack is $133 \mathrm{~mW} \mathrm{~cm}^{-3}$ at $4.2 \mathrm{kWh} \mathrm{Nm}^{-3} \mathrm{H}_{2}$, the corresponding value for a FobAEC-based stack being $2280 \mathrm{~mW} \mathrm{~cm}^{-3}$. The required space for the electrolysis stacks can be reduced by a factor of 20 and the total weight can also be reduced by an order of magnitude by replacing the classical system with a FobAEC-based system. Naturally this would result in a significant reduction in investment cost. It should be emphasized though that the FobAEC-based system has not been proven in large scale; comprehensive research and development is necessary to demonstrate such systems in the coming decades.

More important than the potential to decrease the investment cost is the potential to decrease the hydrogen production cost by operating the FobAEC-based system at higher efficiency, i.e. closer to the thermoneutral voltage, while still achieving higher production rates than with conventional AEC systems. Not only will this operating strategy lead to substantially reduced $\mathrm{H}_{2}$ production cost, it will also overcome the need for cooling. This can lead to substantial system simplification, by avoiding the need for electrolyte recirculation, degasing and cooling circuits. Furthermore, the production of $\mathrm{H}_{2}$ at 50 bar pressure, offers the possibility for reduced size and cost (capital and operating cost) of the compressor that may be used downstream if pressurized storage of $\mathrm{H}_{2}$ at ca. 700 bar is required (e.g. for $\mathrm{H}_{2}$ refueling stations). ${ }^{13}$ All in all, this novel cell concept holds great promise for drastic reduction in system size, capital cost and complexity, while at the same time reducing operating costs.

\section{Conclusions}

Low-cost, large-scale production methods were successfully demonstrated for the first time for the fabrication of a novel type of alkaline electrolysis cells, comprising metal foam based gas diffusion electrodes and a mesoporous ceramic separator. The ceramic separator was produced by tape casting and the assembling of the cells was realized by hot pressing at $200^{\circ} \mathrm{C}$ and sintering at $1000^{\circ} \mathrm{C}$. A record high current density of $3.75 \mathrm{~A} \mathrm{~cm}^{-2}$ was realized at a cell voltage of $1.75 \mathrm{~V}$, at $200^{\circ} \mathrm{C}$ and $20 \mathrm{bar}$, using a $\mathrm{Ni}$ foam based oxygen electrode impregnated with PTFE and Ag nanowires and an Inconel coated $\mathrm{Ni}$ foam hydrogen electrode. Although this current density was recorded during cyclic voltammetry at a sweep rate of $20 \mathrm{mV} / \mathrm{s}$, chronopotentiometry measurements suggest minor deviations from steady state values at least for current densities up to $1 \mathrm{~A} \mathrm{~cm}^{-2}$. Tape casting allowed production of the mesoporous separator at a thickness of only $200 \mu \mathrm{m}$, yielding a serial resistance of only $60 \mathrm{~m} \Omega \mathrm{cm}^{2}$, when filled with $45 \mathrm{wt} \%$ aqueous $\mathrm{KOH}$. The total cell area specific resistance was as low as $148 \mathrm{~m} \Omega \mathrm{cm}^{2}$ in the best case at $200^{\circ} \mathrm{C}$. Replacement of the $\mathrm{Ni}$ foam with a $\mathrm{NiFeCrAl}$ alloy coated $\mathrm{Ni}$ foam for the oxygen electrode yielded very encouraging long-term stability over $400 \mathrm{~h}$ of continuous electrolysis at $500 \mathrm{~mA} \mathrm{~cm}^{-2}$ at $200^{\circ} \mathrm{C}$ and $20 \mathrm{bar}$. The very high power density of the cells can result in more than a 10-fold reduction in stack size, compared to conventional AECs, and equivalent investment cost reduction. More importantly, this novel type of cells allows operation at a much higher electrical efficiency than conventional AECs, thereby promising great reduction in the production cost of $\mathrm{H}_{2}$ by electrolysis.

\section{References}

1. J. Barton and R. Gammon, J. Power Sources, 195, 8222 (2010).

2. A. Evans, V. Strezov, and T. J. Evans, Renew. Sustain. Energy Rev., 16, 4141 (2012).

3. C. Mansilla, J. Louyrette, S. Albou, C. Bourasseau, and S. Dautremont, Energy, 55, 996 (2013).

4. A. Ursua, L. M. Gandia, and P. Sanchis, Proc. IEEE, 100, 410 (2012).

5. J. Ivy (2003) http://www.nrel.gov/docs/fy04osti/36734.pdf.

6. F. Allebrod, C. Chatzichristodoulou, P. L. Mollerup, and M. B. Mogensen, patent Pending No. 12164019.7-2119 (2012).

7. F. Allebrod, C. Chatzichristodoulou, and M. B. Mogensen, J. Power Sources, 229, $22(2013)$

8. F. Allebrod, C. Chatzichristodoulou, and M. B. Mogensen, J. Power Sources, 255, 394 (2014).

9. F. Allebrod, C. Chatzichristodoulou, P. L. Mollerup, and M. B. Mogensen, in International Journal of Hydrogen Energy, 37, 16505 (2012).

10. F. Allebrod, PhD Thesis, Technical University of Denmark (2013).

11. C. Chatzichristodoulou, F. Allebrod, and M. Mogensen, Rev. Sci. Instrum., 84, 054101 (2013).

12. F. Allebrod, C. Chatzichristodoulou, K. Agersted, and M. B. Mogensen, in 5th European PEFC \& H2 Forum, p. 1 (2015).

13. K. Onda, T. Kyakuno, K. Hattori, and K. Ito, J. Power Sources, 132, 64 (2004). 